\title{
Kajian Pemanfaatan Kompos Jerami sebagai Substitusi Pupuk NPK pada Pertumbuhan dan Produksi Padi Sistem IPAT-BO \\ (The Evaluation of Straw Compost Utilization as A Substitute of NPK Fertilizer on The Growth And Production of Rice By IPAT-BO System)
}

\author{
Indrawaty Kadengkang ${ }^{1)^{*}}$, Jeanne M. Paulus ${ }^{1)}$, Edy F. Lengkong ${ }^{1)}$ \\ 1)Program Studi Agronomi, Pasca Sarjana Universitas Sam Ratulangi Manado \\ *Email korespondensi: indrawatikadengkang@gmail.com ${ }^{1)}$
}

Diterima 2 Agustus 2015, diterima untuk dipublikasikan 30 Agustus 2015

\begin{abstract}
Abstrak
Penelitian ini bertujuan untuk mengkaji dosis kompos jerami yang tepat untuk mensubstitusi pupuk NPK pada pertumbuhan dan produksi padi sistem IPAT-BO dengan menggunakan Rancangan Acak Kelompok (RAK) dengan 5 perlakuan dan 4 ulangan. Perlakuan terdiri dari $l_{1}=0 \%$ kompos jerami dan $100 \%$ pupuk NPK, $I_{2}=25 \%$ kompos jerami dan $75 \%$ pupuk NPK, $I_{3}=50 \%$ kompos jerami dan $50 \%$ pupuk NPK; $I_{4}=75 \%$ kompos jerami dan $25 \%$ pupuk NPK dan $I_{5}=100 \%$ kompos jerami dan $0 \%$ pupuk NPK. Hasil penelitian menunjukkan bahwa pemupukan kompos jerami dan pupuk NPK berpengaruh nyata meningkatkan pertumbuhan padi sawah yang meliputi rata-rata tinggi tanaman dan jumlah anakan, namun tidak berpengaruh nyata pada produksi. Rata-rata tinggi tanaman tertinggi pada perlakuan $I_{1}, I_{5}, I_{3}$ dan $I_{2}$ masing-masing $102,28 \mathrm{~cm} ; 101,40 \mathrm{~cm}$; $101,20 \mathrm{~cm}$ dan 100,28 cm. Jumlah anakan per rumpun terbanyak pada perlakuan $I_{3}$ dan $I_{1}$ masing-masing 33,48 anakan/rumpun dan 32,93 anakan/rumpun.

Kata kunci : kompos jerami, IPAT-BO, padi,pupuk NPK
\end{abstract}

\begin{abstract}
This study aimed to assess the proper dosage of straw compost as a substitute of NPK fertilizer on the growth and production of rice by IPAT BO system using a randomized block design (RAK) with 5 treatments and 4 replicates. The treatment consisted of $I_{1}=0 \%$ straw compost and $100 \%$ of NPK, $I_{2}=25 \%$ straw compost and $75 \%$ of NPK, $I_{3}=50 \%$ straw compost and $50 \%$ of $N P K, I_{4}=75 \%$ straw compost and $25 \%$ NPK fertilizer and $I_{5}=100 \%$ straw compost and $0 \%$ NPK fertilizer. The results showed that both of straw compost and NPK fertilizers significantly increased the growth of paddy rice crops, i.e. the plant height and number of tillers, but there was no significant effect on rice production. The highest plant height was observed in the treatments of $I_{1}, I_{5}, I_{3}$ and $I_{2}$, i.e. 102.28, 101.40, 101.20 and $100.28 \mathrm{~cm}$, respectively. The highest number of tillers/clump was in the $I_{3}$ and $I_{1}$ treatments, i.e. 33.48 and 32.93 respectively.

Keywords: IPAT-BO, NPK fertilizer, rice, straw compost
\end{abstract}




\section{PENDAHULUAN}

Tanaman padi (Oryza sativa L.) merupakan tanaman pangan utama di Indonesia. Peningkatan produktivitas padi telah banyak dilakukan oleh pemerintah sehingga pada tahun 1983-1984 Indonesia berhasil swasembada beras. Namun pada tahun 1994, swasembada beras berakhir dengan memunculkan masalah seperti menurunnya produktivitas padi yang diikuti dengan meningkatnya kerusakan lingkungan akibat penggunaan pupuk kimia dan pestisida secara terus-menerus (Badan Litbang Pertanian 2006).

Budidaya padi sawah selama ini masih menitikberatkan pada peningkatan produktivitas dengan penggunaan pupuk kimia. Meskipun penggunaan pupuk kimia meningkatkan produktivitas, tetapi penggunaan pupuk kimia secara terus-menerus memberikan dampak negatif bagi lingkungan. Selain itu penggunaan pupuk kimia yang terus meningkat menyebabkan beban anggaran subsidi pemerintah juga terus meningkat. Pada tahun 2015, kebutuhan pupuk kimia (anorganik) NPK pada tanaman pangan sebanyak 1.857 .441 ton atau naik sekitar 26,66 \% (1.362.272 ton) dari kebutuhan pupuk NPK pada tahun 2014 (Permentan No. 130/ Permentan/ SR.130/11/2014 dan Permentan No.122/ Permentan/ SR.130/11/ 2013). Penyediaan pupuk juga sering mengalami kendala yang diakibatkan sering langkanya pupuk di pasaran akibat kurangnya pengawasan pendistribusian pupuk, tingginya permintaan pupuk dan biaya transportasi yang meningkat. Hal ini juga yang mengakibatkan harga pupuk naik sekitar $10-30 \%$. Petani juga sering menggunakan pupuk dengan dosis yang tidak berimbang akibat keterbatasan modal usaha tani. Padahal di lahan terdapat bahan-bahan yang dapat digunakan sebagai pupuk yaitu jerami padi yang seringkali hanya dibakar oleh petani.

Penerapan teknologi dalam usaha budidaya padi sawah mutlak dilakukan salah satunya adalah dengan Teknologi Intensifikasi Padi Aerob Terkendali Berbasis Organik (IPAT-BO) sehingga perlu dilaksanakan penelitian tentang pemanfaatan kompos jerami sebagai substitusi pupuk NPK pada pertumbuhan dan produksi padi sistem IPAT-BO.

Teknologi Intensifikasi Padi Aerob Terkendali Berbasis Organik (IPAT-BO) dikembangkan oleh tim peneliti Fakultas Pertanian Universitas Padjajaran bekerjasama dengan Kementerian Negara Riset dan Teknologi pada tahun 2007. Menurut Simarmata dan Joy (2010), IPAT-BO merupakan sistem produksi holistik terpadu berbasis input lokal (Kompos jerami, pupuk hayati, dan input lainnya) dengan konsep LEISA ( low external input sustaible agriculture) dan managemen tata air, tanaman dan pemupukan untuk memanfaatkan kekuatan biologis tanaman maupun kekuatan biologis tanah.

Pada penerapan IPAT-BO, ekologis sawah diubah dari tergenang (anaerob) menjadi tidak tergenang atau aerob (lembab hingga macak-macak) sehingga akan mempengaruhi pertumbuhan (anakan dan perkembangan sistem perakaran). Intensifikasi padi sawah dengan sistem tergenang (anaerob) tidak saja menyebabkan tidak berfungsinya kekuatan biologis tanah tetapi juga menghambat sistem perakaran tanaman padi. Selain itu penerapan IPAT-BO dapat meningkatkan kekuatan biologis tanaman padi, hasil kajian memperlihatkan bahwa padi memiliki potensi untuk menghasilkan anakan yang sangat banyak tergantung pada jarak tanam dan jumlah bibit yang ditanam. Dengan jarak tanam lebar dan pasokan nutrisi yang baik maka 
padi dapat memanfaatkan sinar matahari secara optimum dan mampu menghasilkan sekitar 80-100 anakan per rumpun. IPAT-BO juga menerapkan pola pemupukan terpadu. Mutu intensifikasi usaha pertanian padi sawah harus menerapkan pengelolaan berbagai sumber hara tanaman yang berasal dari tanah, pupuk kimia, pupuk organik dan bahan organik sisa panen tanaman padi (Sisworo 2006). Dosis dan waktu aplikasi pupuk pada tanaman padi sawah dapat dilihat di Tabel 1.

Petani sering menggunakan pupuk majemuk paket pupuk NPK/phonska dan urea. Komposisi pupuk NPK phonska adalah Nitrogen (N) $15 \%$, Fosfat $\left(\mathrm{P}_{2} \mathrm{O}_{5}\right) 15 \%$, Kalium $\left(\mathrm{K}_{2} \mathrm{O}\right) 15 \%$, dan Sulfur $(\mathrm{S}) 10 \%$.

Tabel 1. Dosis dan waktu aplikasi pupuk pada tanaman padi sawah

\begin{tabular}{lccc}
\hline \multirow{2}{*}{$\begin{array}{c}\text { Waktu } \\
\text { Aplikasi }\end{array}$} & \multicolumn{3}{c}{$\begin{array}{c}\text { Jenis dan Takaran (kg } \\
\text { ha-1) }\end{array}$} \\
\cline { 2 - 4 } & $\begin{array}{c}\text { Pupuk } \\
\text { Organik }\end{array}$ & NPK & Urea \\
\hline $\begin{array}{l}\text { Pupuk } \\
\text { Dasar }\end{array}$ & 500 & 150 & 50 \\
\hline $\begin{array}{l}\text { Susulan I } \\
\text { (15-20 } \\
\text { HST) }\end{array}$ & - & 150 & 50 \\
\hline $\begin{array}{l}\text { Susulan } \\
\text { II (30-35 } \\
\text { HST) }\end{array}$ & - & - & 100 \\
\hline \multicolumn{1}{l}{ Jumlah } & 500 & 300 & 200 \\
\hline $\begin{array}{l}\text { Sumber : Buku panduan pemupukan } \\
\text { PT. Petrokimia Gresik (2014) }\end{array}$
\end{tabular}

$\begin{array}{ccc}\begin{array}{c}\text { Tanaman } \\ \text { memerlukan }\end{array} \text { pupuk } & \text { sawah } \\ \text { yang }\end{array}$ mengandung unsur hara makro. Selain itu, terdapat unsur hara bukan essensial tetapi sangat diperlukan oleh tanaman padi yaitu silikat (Si), namun pemupukan Si pada tanah sawah belum umum dilakukan. Unsur hara $\mathrm{N}$, $\mathrm{P}$, dan $\mathrm{K}$ umumnya dikembalikan ke dalam tanah melalui pemupukan, namun unsur $\mathrm{Si}$ umumnya tidak dikembalikan ke dalam tanah. Sumber silikat dilahan sawah adalah jerami padi. Setiap hektar sawah akan menghasilkan sekitar 8-12 ton jerami (sekitar 1,5 x hasil gabah) per musim atau setara dengan 4-6 ton kompos jerami/ha/musim. Potensi jerami sebagai pupuk disajikan dalam Tabel 2.

Tabel 2. Potensi jerami dalam mensubstitusi pupuk anorganik

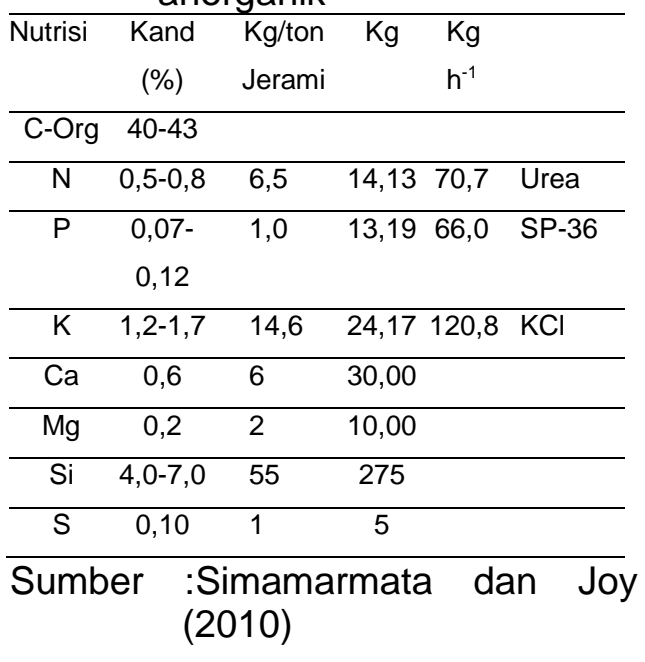

Tabel 2 memperlihatkan bahwa pemanfaatan jerami atau kompos jerami, dapat mengurangi penggunaan pupuk kimia hingga $50 \%$ terutama unsur hara $\mathrm{K}$ dan $\mathrm{Si}$. Penggunaan kompos jerami sekitar 4-6 ton ha-1 mampu memasok kebutuhan hara $\mathrm{K}$ dan $\mathrm{Si}$ dengan tingkat produktivitas sekitar $6-8$ ton ha $^{-1}$.

Pembuatan kompos belum dipraktekkan secara luas oleh petani dikarenakan belum tersedianya alat pencacah jerami maupun rumah kompos. Kendala lainnya adalah memerlukan biaya dan tenaga untuk mengangkut jerami dari lahan. Alternatif yang mudah dipraktekkan oleh petani adalah dengan pengomposan langsung di sawah. Untuk mempercepat proses pengomposan digunakan dekomposer (mikroba perombak 
bahan organik beragen hayati) EM4 atau bisa menggunakan MOL (Makarim et al. 2007).

Penelitian ini bertujuan bertujuan mengkaji dosis kompos jerami yang tepat untuk mensubstitusi pupuk NPK pada pertumbuhan dan produksi padi sistem IPAT-BO.

\section{METODE}

Penelitian ini dilaksanakan di Kelurahan Motoboi Besar, Kecamatan Kotamobagu Timur, Kota Kotamobagu dari bulan April sampai dengan bulan Agustus 2015. Bahan penelitian pada tahap 1 pembuatan kompos jerami menggunakan bahan yaitu jerami padi, dedak halus, gula pasir, EM4 dan air. Bahan yang digunakan pada tahap II budidaya padi sawah dengan metode intensifikasi yaitu bibit padi varietas Ciherang, pupuk NPK, pupuk urea, dan pestisida. Alat yang digunakan yaitu cetakan dari bambu, sekop, cangkul, label, plastik, kamera, kalkulator, perangkat komputer, timbangan, penggaris, alat tulis.

Penelitian ini disusun dalam Rancangan Acak Kelompok (RAK) dengan faktor tunggal yaitu perlakuan kompos jerami dan pupuk NPK dengan 5 perlakuan, rekomendasi umum penggunaan kompos jerami 10 ton ha-1 dan pupuk NPK $300 \mathrm{~kg} \mathrm{ha}^{-1}$. Perlakuan terdiri dari:

$\mathrm{I}_{1}=0 \%$ kompos jerami $\left(0 \mathrm{~kg} \mathrm{ha}^{-1}\right)$ dan $100 \%$ pupuk NPK (300 kg ha-1)

$\mathrm{I}_{2}=25 \%$ kompos jerami (2,5 ton ha

$\left.{ }^{1}\right)$ dan $75 \%$ pupuk NPK (225 kg ha-1) $\mathrm{I}_{3}=50 \%$ kompos jerami ( 5 ton ha-1) dan $50 \%$ pupuk NPK $\left(150 \mathrm{~kg} \mathrm{ha}^{-1}\right)$ $\mathrm{I}_{4}=75 \%$ kompos jerami $(7,5$ ton ha

$\left.{ }^{1}\right)$ dan $25 \%$ pupuk NPK (75 kg ha-1) $I_{5}=100 \%$ kompos jerami (10 ton ha-

$\left.{ }^{1}\right)$ dan $0 \%$ pupuk NPK (0 kg ha-1)

Pelaksanaan penelitian ini dilaksanakan dalam 2 tahap. Tahap I meliputi pembuatan kompos secara in situ (langsung sawah) dengan cara difermentasi selama 1 bulan. Tahap
II meliputi budidaya padi sawah dengan sistem intensifikasi padi aerob terkendali yang didahului dengan pengolahan tanah sempurna sebanyak 3 kali, yaitu 1 kali bajak dan 2 kali garu (pelumpuran). Kemudian dilanjutkan dengan pembuatan petakan masing-masing berukuran 4 $x 3 \mathrm{~m}$ sesuai dengan banyaknya kelompok ulangan dan perlakuan. Di antara petakan dibuat saluran air untuk memasukkan dan mengeluarkan air dengan lebar dan dalam $30 \mathrm{~cm}$. Perlakuan dan penyemaian benih di lahan persemaian dengan tinggi $10-20 \mathrm{~cm}$ dan lebar $2 \mathrm{~m}$. Penanaman dilakukan dengan sistem pindah tanam setelah bibit berumur 15 hari dengan sistem tanam tegel $30 \mathrm{~cm} \times 30 \mathrm{~cm}$. Bibit ditanam dengan teknik tanam kembar (twin seedling), yaitu setiap titik ditanam dua bibit berjarak $5 \mathrm{~cm}$ dengan mendorong bibit ke depan hingga kedalaman $1 \mathrm{~cm}$ serta akar dan batang tanaman membentuk huruf $L$.

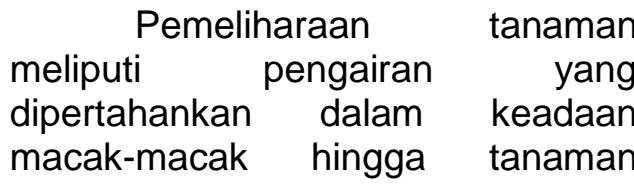
masak susu. Penggenangan 1-2 cm dilakukan 1-2 hari sebelum penyiangan dan menekan pembentukan anakan pada saat tanaman bunting (Flowering stage). Penyiangan dilakukan 2-3 kali. Pemupukan dilakukan dengan menggunakan pemupukan majemuk dengan menggunakan pupuk dasar kompos silika, NPK/phonska dan pupuk urea. Dosis pupuk NPK/phonska diberikan sesuai dengan perlakuan pada penelitian (5 perlakuan) dengan cara aplikasi pupuk kompos jerami diaplikasikan keseluruhannya sesuai perlakuan sebelum pengolahan tanah. Pengendalian hama penyakit dilakukan secara terpadu dan untuk meningkatkan produktivitas diberikan pupuk pelengkap cair dalam bentuk mol. Panen dilaksanakan ketika 95\% 
gabah telah menguning dan daun bendera telah mengering, dan kerontokan gabah sekitar $16-30 \%$.

Variabel yang diamati dalam penelitian ini adalah pengamatan pada saat panen yang meliputi tinggi tanaman (diukur dari permukaan tanah sampai ujung malai), jumlah anakan, jumlah anakan produktif, panjang malai dan jumlah bulir per malai yang diamati dari 10 rumpun contoh yang ditentukan secara acak pada setiap petak percobaan; jumlah gabah berisi yaitu rata-rata jumlah gabah berisi per malai yang terdapat pada 10 rumpun contoh yang diambil secara acak dari setiap petak percobaan; bobot 1000 butir gabah isi; hasil panen (produktivitas) secara ubinan (timbangan hasil plot ubinan $2,5 \times 2,5 \mathrm{~m})$. Data penelitian dari semua variabel pengamatan dianalisis dengan analisis sidik ragam (ANOVA) dan jika terdapat perbedaan diantara perlakuan dilanjutkan dengan uji BNT 5\%.

\section{HASIL DAN PEMBAHASAN \\ Tinggi Tanaman}

Hasil analisis sidik ragam menunjukkan bahwa rata-rata pertumbuhan tinggi tanaman padi sawah pada saat panen berbeda nyata. Perlakuan $I_{4}$ dengan kombinasi pemupukan kompos jerami $75 \%$ dan NPK $25 \%$ menunjukkan hasil yang lebih rendah daripada perlakuan yang lain. Tinggi tanaman padi saat panen tertinggi adalah pada perlakuan $I_{1}$ yaitu $102,275 \mathrm{~cm}$ yang diperoleh dari perlakuan $100 \%$ NPK dan 0\% kompos jerami diikuti dengan perlakuan $I_{5}, I_{3}, I_{2}$ dan yang terendah adalah pada perlakuan $\mathrm{I}_{4}$.

Berdasarkan hasil uji BNT $(0,05)$ diperoleh data bahwa pengaruh pemberian kompos jerami $75 \%$ dan NPK $25 \%$ pada perlakuan $\mathrm{I}_{4}$ menghasilkan rata-rata pertumbuhan tinggi tanaman yang paling rendah yaitu $91,83 \mathrm{~cm}$ hal ini disebabkan terjadinya mobilisasi unsur $\mathrm{N}$ oleh jerami yang sangat diperlukan dalam proses pertumbuhan tanaman. Dosis $75 \%\left(7,5\right.$ ton $\left.\mathrm{h}^{-1}\right)$ kompos jerami belum mencukupi kebutuhan tanaman akan unsur $\mathrm{N}$ meskipun dikombinasikan dengan penambahan 25\% NPK pada perlakuan $\mathrm{I}_{4}$.

Tabel 3. Rata-rata pertumbuhan tinggi tanaman saat panen

\begin{tabular}{crrr}
\hline Perlakuan & $\begin{array}{c}\text { Tinggi } \\
\text { Tanaman }\end{array}$ & Notasi \\
\hline & $\ldots \mathrm{cm} \mathrm{\ldots}$ & & \\
$\mathrm{I}_{1}$ & 102,28 & $\mathrm{a}$ & \\
$\mathrm{I}_{5}$ & 101,40 & $\mathrm{a}$ & \\
$\mathrm{I}_{3}$ & 101,20 & $\mathrm{a}$ & \\
$\mathrm{I}_{2}$ & 100,28 & $\mathrm{a}$ & \\
$\mathrm{I}_{4}$ & 91,83 & & $\mathrm{~b}$ \\
\hline BNT $_{(0,05)}$ & 6,18 & & \\
\hline
\end{tabular}

\section{Jumlah Anakan}

Hasil analisis sidik ragam menunjukkan jumlah total anakan per rumpun tanaman padi sawah pada perlakuan $\mathrm{I}_{3}$ berbeda nyata dengan perlakuan $I_{4}$ dan $I_{2}$. Jumlah total anakan per rumpun pada $I_{2}$ berbeda nyata dengan perlakuan $I_{3}$ dan $I_{1}$ (Tabel 4).

Berdasarkan hasil uji BNT $(0,05)$ diperoleh bahwa pengaruh pemberian kompos jerami $50 \%$ dan NPK $50 \%$ pada perlakuan $I_{3}$ menghasilkan rata-rata jumlah anakan padi sawah yang paling banyak yaitu 33,48 anakan/rumpun diikuti perlakuan $I_{1}, I_{5}, I_{4}$ dan yang terendah adalah pada perlakuan $I_{2}$ yaitu 91,83 anakan/rumpun. Hal ini diakibatkan ketersediaan unsur hara terutama unsur $\mathrm{N}$ pada perlakukan $\mathrm{I}_{3}$ dan $\mathrm{I}_{2}$ mencukupi dalam proses pertumbuhan tanaman. Unsur $\mathrm{N}$ bagi tanaman padi merupakan unsur penyusun asam amino, asam nukleat dan klorofil yang penting bagi tanaman padi dalam mempercepat pertumbuhan (pertambahan tinggi dan jumlah anakan) dan meningkatkan ukuran daun, jumlah 
gabah/malai, persentase gabah isi dan kandungan protein gabah (Doberman and Fairhust 2002). Hasil penelitian Amrah (2008) menunjukkan kombinasi perlakuan bahan organik dan pupuk anorganik meghasilkan jumlah anakan yang lebih banyak jika dibandingkan dengan perlakuan bahan organik saja.

Tabel 4. Rata-rata jumlah anakan saat panen

\begin{tabular}{ccc}
\hline Perlakuan & $\begin{array}{c}\text { Jumlah } \\
\text { Anakan }\end{array}$ & Notasi \\
\hline \multicolumn{3}{c}{ anakan/rumpun } \\
$\mathrm{I}_{3}$ & 33,48 & $\mathrm{a}$ \\
$\mathrm{I}_{1}$ & 32,93 & $\mathrm{a} \mathrm{b}$ \\
$\mathrm{I}_{5}$ & 31,75 & $\mathrm{a} \mathrm{b} \mathrm{c}$ \\
$\mathrm{I}_{4}$ & 31,03 & $\mathrm{~b} \mathrm{c}$ \\
$\mathrm{I}_{2}$ & 30,40 & $\mathrm{c}$ \\
\hline BNT $_{(0,05)}$ & 2,10 & \\
\hline
\end{tabular}

\section{Jumlah Anakan Produktif}

Jumlah total anakan produktif per rumpun tanaman padi sawah pada semua perlakuan tidak berbeda nyata pada saat panen (Tabel 5).

Tabel 5. Rata-rata jumlah anakan produktif

\begin{tabular}{cc}
\hline Perlakuan & $\begin{array}{c}\text { Jumlah Anakan } \\
\text { Produktif }\end{array}$ \\
\hline$I_{3}$ & 11,60 \\
$I_{1}$ & 11,50 \\
$I_{5}$ & 11,28 \\
$I_{2}$ & 11,18 \\
$I_{4}$ & 10,80 \\
\hline BNT $_{(0,05)}$ & 1,82 \\
\hline
\end{tabular}

\section{Panjang Malai, Jumlah Gabah per Malai dan Jumlah Gabah Berisi per Malai}

Panjang malai (Tabel 6), jumlah gabah (Tabel 7) dan jumlah gabah berisi per malai (Tabel 8) tidak berbeda nyata pada semua perlakuan

\begin{tabular}{cc} 
Tabel 6. & Rata-rata panjang malai \\
\hline Perlakuan & Panjang Malai $(\mathrm{cm})$ \\
\hline$I_{3}$ & 20,38 \\
$I_{1}$ & 20,05 \\
$I_{2}$ & 19,98 \\
$I_{4}$ & 19,95 \\
$I_{5}$ & 19,73 \\
\hline BNT $_{(0,05)}$ & 1,87 \\
\hline
\end{tabular}

Tabel 7. Rata-rata jumlah gabah per malai

\begin{tabular}{cc}
\hline Perlakuan & $\begin{array}{c}\text { Jumlah gabah per malai } \\
\text { (butir) }\end{array}$ \\
\hline $\mathrm{I}_{3}$ & 135,70 \\
$\mathrm{I}_{2}$ & 132,50 \\
$\mathrm{I}_{4}$ & 132,48 \\
$\mathrm{I}_{1}$ & 130,63 \\
$\mathrm{I}_{5}$ & 130,20 \\
\hline BNT $_{(0,05)}$ & 20,78 \\
\hline
\end{tabular}

Tabel 8. Rata-rata jumlah gabah berisi per malai

\begin{tabular}{cc}
\hline Perlakuan & $\begin{array}{c}\text { Jumlah gabah per malai } \\
\text { (butir) }\end{array}$ \\
\hline $\mathrm{I}_{3}$ & 103,08 \\
$\mathrm{I}_{1}$ & 102,13 \\
$\mathrm{I}_{2}$ & 100,63 \\
$\mathrm{I}_{4}$ & 100,08 \\
$\mathrm{I}_{5}$ & 99,70 \\
\hline BNT $_{(0,05)}$ & 5,03 \\
\hline
\end{tabular}

\section{Berat 1000 Butir Gabah Berisi dan Hasil Panen}

Hasil analisis sidik ragam menunjukkan berat 1000 butir gabah berisi (Tabel 9) dan hasil panen (Tabel 10) tidak berbeda nyata pada semua perlakuan.

Tabel 9. Berat 1000 butir gabah berisi

\begin{tabular}{cc}
\hline Perlakuan Berat 1000 butir gabah \\
$(\mathrm{g})$
\end{tabular}


Tabel 10. Hasil panen

\begin{tabular}{cc}
\hline \multicolumn{2}{c}{ Perlakuan Hasil Panen $(\mathrm{kg})$} \\
\hline $\mathrm{I}_{3}$ & 2,86 \\
$\mathrm{I}_{1}$ & 2,79 \\
$\mathrm{I}_{2}$ & 2,68 \\
$\mathrm{I}_{5}$ & 2,63 \\
$\mathrm{I}_{4}$ & 2,51 \\
\hline BNT $_{(0,05)}$ & 0,71 \\
\hline
\end{tabular}

Hasil analisis sidik ragam pengaruh pemupukan kompos jerami dan pupuk NPK menunjukkan perbedaan nyata pada pertumbuhan vegetatif tanaman padi sawah tetapi tidak berbeda nyata pada pertumbuhan fase generatif tanaman yang mempengaruhi produksi tanaman. Hal ini disebabkan karena kandungan unsur hara dalam kompos jerami tidak sepenuhnya tersedia pada perkembangan tanaman terutama dalam fase generatif. Pembuatan kompos jerami secara in situ (langsung dilahan) tanpa dicacah terlebih dahulu belum sepenuhnya membuat jerami terurai hal ini dapat dilihat dari hasil uji tanah sebelum dan sesudah dilaksanakan penelitian yang diambil pada setiap petak perlakuan. Jerami mengandung silika dan selulosa yang tinggi sehingga proses pelapukannya memerlukan waktu yang lama (Makarim et al. 2007).

Aplikasi jerami terlihat tidak meningkatkan kandungan $\mathrm{N}, \mathrm{P}, \mathrm{K}$ dan kadar $\mathrm{C} / \mathrm{N}$ hal ini mengindikasikan terjadinya pelepasan unsur Nitrogen ke larutan tanah karena proses dekomposisi jerami yang cukup lama. Unsur nitrogen diperlukan sepanjang fase pertumbuhan dan perkembangan tanaman. Pada proses pertumbuhan nitrogen diperlukan terutama pada fase awal sampai pertengahan pembentukan anakan sedangkan pada fase perkembangan diperlukan pada tahap awal pembentukan malai. Suplai nitrogen selama proses pemasakan diperlukan untuk menunda gugurnya daun, memelihara fotosintesis selama pengisian biji dan meningkatkan kadar protein dalam biji (Doberman and Fairhust 2002). Jerami padi yang dibenamkan ke tanah sawah pada awalnya akan mengimobilisasi $\mathrm{N}$ tersedia pada tanah. Unsur $\mathrm{N}$ yang terikat jerami berkurang dengan semakin tingginya konsentrasi $\mathrm{N}$ dalam jerami dan suhu tanah. Proses dekomposisi jerami akan melepas $\mathrm{N}$ (remineralisasi). Pemberian jerami pada lahan sawah menyebabkan $\mathrm{N}$ tanah terserap kedalam jaringan jerami sebelum jerami dirombak oleh jasad renik di dalam tanah. Proses ini menyebabkan kandungan hara dalam tanah turun sehingga berpotensi kahat N. Semakin banyak jerami yang diberikan semakin parah tanaman kekurangan $\mathrm{N}$ (Makarim et al. 2007).

Hasil penelitian Sugiyanta (2007) menunjukkan aplikasi bahan organik mampu meningkatkan kadar $\mathrm{N}$ secara bertahap dan baru nyata terlihat menambah akumulasi $\mathrm{N}$ dalam tanah pada aplikasi pada musim tanam ketiga.

Nilai $\mathrm{pH}$ sebelum perlakuan dan pada saat perlakuan $I_{1}$ dan $I_{2}$ adalah netral dan $\mathrm{pH}$ pada perlakuan $I_{3}, I_{4}$ dan $I_{5}$ adalah agak masam dengan nilai berturut-turut 6,$55 ; 6,44$; dan 6,35. Hal ini sesuai dengan penelitian Hartatik dan Setyorini (2008) yang menyatakan bahwa aplikasi pupuk organik menyumbangkan asam-asam organik yang meningkatkan kemasaman tanah. Pada tanah asam ( $\mathrm{pH}$ rendah), tanah didominasi oleh ion $\mathrm{Al}$, $\mathrm{Fe}$, dan $\mathrm{Mn}$ yang akan mengikat unsur hara yang sangat dibutuhkan tanaman terutama unsur $\mathrm{P}$ (fosfor), K (kalium), S (sulfur), Mg (magnesium) dan Mo (Molibdenum) sehingga tanaman tidak bisa menyerap makanan dengan baik meskipun kandungan unsur hara dalam tanah banyak. Selain itu, ionion tersebut juga dapat meracuni 
tanaman. Pada tanah asam juga terdapat kandungan unsur hara mikro seperti Zn (seng), Cu (tembaga) dan Co (kobalt) juga tinggi sehingga dapat meracuni tanaman (Kurnianti, 2013). Selain pengapuran dengan pemberian dolomit, pengelolaan air juga sangat dibutuhkan dalam menetralkan $\mathrm{pH}$ terutama dalam pencucian bahan-bahan beracun (Suriadikarta 2005).

Terjadi serangan hama penyakit yaitu pada saat tanaman padi berumur 26 hst terserang penyakit bercak daun cercospora dan blas. Dari hasil penelitian Suprihanto dkk (2008) dilaporkan bahwa varietas ciherang rentan terhadap serangan penyakit bercak daun cercospora dibandingkan varietas lainnya.

Curah hujan yang cukup tinggi pada awal penelitian menyebabkan cepat berkembangnya jamur Pyricularia grisea penyebab penyakit blas yang dapat menginfeksi pada semua fase pertumbuhan. Pada fase generatif jamur ini akan berkembang pada tangkai/leher malai yang disebut blas leher sehingga mempengaruhi proses pengisian gabah yang mengakibatkan banyak terdapat bulir gabah hampa. Faktor lain yang dapat menyebabkan blas adalah kondisi aerobik dan sumber inokulumnya adalah jerami (Balai Besar Penelitian Tanaman Padi 2015).

Serangan hama juga terjadi pada saat tanaman padi berumur 41 hst dimana tanaman terserang hama kepinding tanah. Curah hujan pada saat itu juga cukup tinggi yaitu 151,5 $\mathrm{mm}^{3}$. Sistem budidaya dengan menggunakan IPAT-BO yang tidak menggenangi lahan menyebabkan hama kepinding tanah masuk dan menyerang sampai pada perakaran tanaman padi sawah.

Meskipun demikian sistem budidaya IPAT-BO menunjukkan waktu panen yang lebih cepat. Varietas padi Ciherang pada penelitian ini dipanen saat berumur
97 hst atau lebih cepat 19-28 hari dari deskripsi umur padi Ciherang. Hasil ini sesuai dengan hasil penelitian Simarmata dan Joy (2010) yang menyatakan bahwa keunggulan dari IPAT-BO adalah hemat air, hemat bibit, hemat pupuk, hemat pestisida dan panen lebih awal.

Lahan penelitian yang digunakan juga merupakan lahan yang baru untuk penerapan pupuk organik. Hasil penelitian Amrah (2008) menunjukkan aplikasi bahan organik berupa jerami saja dapat memberikan hasil gabah yang tidak berbeda jika dibandingkan dengan jerami yang dikombinasikan dengan pupuk anorganik pada musim tanam ke-9. Hasil penelitian Tualar dan Joy (2010) menunjukkan aplikasi kompos jerami selama 4-6 musim tanam mampu meningkatkan kesehatan tanah dan meningkatkan produktivitas padi sekitar $25 \%$. Sedangkan dari hasil penelitian dari Ningtias dan Suharjanto (2012) diperoleh bahwa pertumbuhan tanaman padi tidak menunjukkan perbedaan yang nyata pada pelaksanaan penelitian sitem budidaya IPAT-BO dengan perlakuan jumlah bibit dikarenakan pertumbuhan tanaman dipengaruhi kondisi lingkungan yaitu media tanam dan iklim.

Penelitian selanjutnya sebaiknya dilakukan kajian lebih mendalam tentang pengolahan kompos jerami dengan dicacah lebih dahulu sehingga jerami dapat cepat terurai secara sempurna, sehingga unsur hara dapat tersedia bagi pertumbuhan dan produksi tanaman.

\section{KESIMPULAN}

Pemupukan dengan kompos jerami dan pupuk NPK berpengaruh nyata pada pertumbuhan tanaman padi sawah yang meliputi rata-rata tinggi tanaman dan jumlah anakan, tetapi tidak berpengaruh nyata pada produksi. 
DAFTAR PUSTAKA

Amrah ML (2008) Pengaruh manajemen jerami terhadap pertumbuhan dan produksi padi sawah ( Oryza sativa L.) Tesis Program Agronomi Fakultas Pertanian Departemen Budidaya Pertanian. Institut Pertanian Bogor

Badan Litbang Pertanian (2006) Rekomendasi pemupukan N, $\mathrm{P}, \mathrm{K}$ pada padi sawah spesifik lokasi. Kementerian Pertanian. Jakarta

Balai Besar Penelitian Tanaman Padi. 2015. Penyakit blas pada tanaman padi dan cara pengendaliannya. Publikasi Buklet. http: //bbpadi. litbang. pertanian. go. id/index. php/ publikasi/booklet-leafletposter/ content/ item/ 162penyakit-blas. Balitbangtan

Kementrian pertanian. Sukamandi Jawa Barat .Diakses pada tanggal 29 Oktober 2015

Dobermann A, Fairhurst TH (2002) Rice straw management. Better Crops International 16: 7-11

Hartatik W, Setyorini D (2008) Validasi rekomendasi pemupukan NPK dan pupuk organik pada padi sawah. Balittanah.litbang.pertanian.g o.id Diakses tanggal 29 Oktober 2015

Kurnianti N (2013) pH Tanah. http://www.tanijogonegoro.co m/2013/05/ph-tanah.html. Diakses tanggal 29 Oktober 2015

Makarim AK, Sumarno, Suyamto (2007) Jerami padi: pengelolaan dan pemanfaatan. Pusat Penelitian dan Pengembangan Tanaman Pangan. Badan Penelitian dan Pengembangan Pertanian. Bogor
Ningtias EM, Suharjanto T (2012) Sistem intensifikasi padi aerob terkendali berbasis organik di Kelurahan Tunggulwulung, Kota Malang. Jurnal AGRIKA 6 (1)

Permentan No 122/ Permentan/ SR.130/11/2013. Tanggal 26 Nopember 2013. Kebutuhan dan harga eceran Tertinggi (pupuk bersubsidi) Tahun 2014. Kementrian Pertanian. Jakarta

Permentan No 130/ Permentan/ SR.130/11/2014. Tanggal 27 Nopember 2014. Kebutuhan dan Harga Eceran Tertinggi (HET) Pupuk bersubsidi untuk sektor Pertanian Tahun Anggaran 2015. Kementrian Pertanian. Jakarta

Petrokimia Gresik (2014) Buku Panduan Pemupukan. PT Petrokimia Gresik

Puslitbangtanak (2004) Tanah sawah dan teknologi pengelolaannya. Pusat Penelitian dan Pengembangan Tanah dan Agroklimat (Puslitbangtanak). Bogor

Simarmata T, Joy B (2010) Pemulihan kesehatan dan peningkatan produksi padi pada lahan suboptimal dengan teknologi intensifikasi padi aerob terkendali berbasis organik (IPAT-IBO). Makalah. Fakultas Pertanian Universitas Padjajaran. Bandung

Sisworo WH (2006) Swasembada pangan dan pertanian berkelanjutan. Tantangan abad dua satu. Badan Tenaga Nuklir Indonesia. Jakarta

Sugiyanta (2007) Peran jerami dan pupuk hijau Crotalaria juncea terhadap efisiensi dan kecukupan hara lima varietas padi sawah. Disertasi. 
78 JURNAL BIOSLOGOS, AGUSTUS 2015, VOL. 5 NOMOR 2

Sekolah Pascasarjana Institut Pertanian Bogor.

Suprihanto, Guswara A, Satoto (2008) Pengaruh dosis pupuk nitrogen terhadap beberapa penyakit pada varietas padi hibrida. Balai Besar Penelitian Tanaman Padi. Sukamandi Jawa Barat
Suriadikarta DA (2005) Pengelolaan lahan sulfat masam untuk usaha pertanian. Jurnal Litbang Pertanian (24) I. http: //www. scribd. com/doc/225540881/ Pengelolaan-Lahan-SulfatAsam. Diakses tanggal 29 Oktober 2015 